\title{
Spektroskopia w podczerwieni z transformatą Fouriera w analizie składu kamieni nerkowych
}

\section{Fourier transform infrared spectroscopy for analysis of the composition of kidney stones}

\author{
Renata Beata Szydlak ${ }^{\boxplus}$, Piotr Maciukiewicz ${ }^{2}$ \\ ${ }^{1}$ Uniwersytet Jagielloński, Collegium Medicum, Katedra Biochemii Lekarskiej, ul. Kopernika 7, 31-034 Kraków \\ Jagiellonian University, Medical College, Department of Medical Biochemistry \\ ${ }^{2}$ Szpital Specjalistyczny im. Ludwika Rydygiera w Krakowie, Odział Urologii, os. Złotej Jesieni 1, 31-826 Kraków \\ Specialist Hospital Louis Rydygiera in Cracow, Department of Urology \\ $\triangle$ renata.szydlak@uj.edu.pl
}

\begin{abstract}
Introduction: Kidney stones are one of the most common diseases of the urinary tract, caused by metabolic and excretory disorders. Identification of the components of the stone is necessary to determine the cause of the formation of deposits and to choose the appropriate therapy.

The aim of the study was to determine the chemical composition of the kidney stones.

Materials and methods: Kidney stones recovered from 46 patients were analyzed for their chemical composition by Fourier
\end{abstract}

transform infrared spectroscopy (FTIR). The resulting FTIR spectra of the kidney stones were compared to standards.

Results: Of the 46 samples, $58.3 \%$ were comprised calcium oxalate, $28.3 \%$ struvites and $10.9 \%$ uric acid. Gender analysis showed that $69.6 \%$ of the examined stones were from men and $30.4 \%$ from women. Comparison with age revealed that the majority of respondents are people aged 30-44.

Conclusions: Calcium oxalate, struvites and uric acid are commonly occurring kidney stones.

Keywords: kidney stones; Fourier transform infrared spectroscopy (FTIR); calcium oxalate; struvites; uric acid.

\section{ABSTRAKT}

Wstęp: Kamica nerkowa jest jedną z najczęstszych chorób układu moczowego, której przyczyną są zaburzenia metaboliczne i wydalnicze. Identyfikacja składników kamieni nerkowych jest niezbędna do określenia przyczyny powstawania złogów i doboru odpowiedniej terapii leczenia.

Celem badań było określenie składu chemicznego kamieni nerkowych.

Materiały i metody: Kamienie nerkowe pobrane od 46 pacjentów analizowano pod kątem składu chemicznego, za pomocą spektroskopii w podczerwieni z transformatą Fouriera (FTIR). Otrzymane widma FTIR kamieni nerkowych porównano ze standardami.
Wyniki: Z 46 próbek 58,3\% stanowiły kamienie zbudowane ze szczawianu wapnia, 28,3\% - kamienie struwitowe, a 10,9\% kamienie kwasu moczowego. Analiza względem płci pokazała, że 69,6\% badanych kamieni pochodziło od mężczyzn, a 30,4\% od kobiet. Porównanie względem wieku ujawniło, że najwięcej badanych znajduje się w przedziale wiekowym 30-44 lat.

Wnioski: Szczawian wapnia, struwit i kwas moczowy są powszechnie spotykanymi kamieniami nerkowymi.

Słowa kluczowe: kamica nerkowa; spektroskopia w podczerwieni z transformatą Fouriera (FTIR); szczawian wapnia; struwit; kwas moczowy.

\section{WSTĘP}

Kamica nerkowa jest jedną z najczęstszych chorób układu moczowego o wieloczynnikowej etiopatogenezie [1]. Kamica układu moczowego występuje u $2 \%$ populacji i dotyczy ok. 2-3-krotnie częściej mężczyzn niż kobiet. Bez profilaktyki, po usunięciu pierwszego w życiu złogu u 50\% chorych dochodzi do nawrotu kamicy w ciągu 5 lat, a u 60-80\% w ciągu 10 lat [2]. W większości przypadków przyczyną powstawania kamieni są zaburzenia metaboliczne i wydalnicze. Badania kliniczne i epidemiologiczne dowiodły, że istnieje kilka czynników ryzyka zaangażowanych w etiologię tej choroby. Są to m.in. nawyki żywieniowe, ciepły klimat, występowanie rodzinne $[1,3]$. Identyfikacja składników kamieni nerkowych jest niezbędna, ponieważ dostarcza informacji o przyczynach powstawania złogów i umożliwia dobór odpowiedniej terapii. Niestety, skład kamieni jest niejednorodny i różni się w obrębie populacji [4]. Analiza składu chemicznego kamieni umożliwia poznanie ich etiologii i dobór odpowiedniej strategii leczenia oraz zapobieganie nawrotom choroby. Spektroskopia w zakresie promieniowania podczerwonego umożliwia analizę składu chemicznego kamieni nerkowych na podstawie charakterystycznych dla określonych wiązań i grup funkcyjnych drgań molekuł [5, 6]. Rutynowe, łatwe i szybkie pomiary dostarczają jednoznacznych informacji na temat kompozycji kamienia. W szczególności precyzja metody Fouriera jest tutaj pomocna 
ze względu na relatywnie dobrą rozdzielczość przestrzenną, ponieważ kamienie często zbudowane są z rdzenia i kilku warstw o różnym składzie chemicznym.

W niniejszej pracy przedstawiono analizę kamieni od 46 pacjentów i określono ich możliwe czynniki etiologiczne dla doboru skuteczniejszej terapii.

\section{MATERIAŁY I METODY}

Materiałami do przeprowadzenia niniejszego badania były kamienie nerkowe pobrane od 46 pacjentów (32 mężczyzn i 14 kobiet w wieku 15-63 lat). Wszystkie kamienie, usunięte podczas operacji, zostały umieszczone na sterylnej siatce drucianej, wysuszone na powietrzu, a następnie przeniesione do papierowej plastikowej koperty z numerem próbki. Wszystkie próbki zostały najpierw dokładnie przemyte destylowaną wodą dejonizowaną, a następnie były suszone na żelu krzemionkowym przez kilka dni. Po odnotowaniu cech morfologicznych, takich jak kolor, kształt itp., kamienie nerkowe od każdego pacjenta pocięto na ćwiartki za pomocą piły jubilerskiej, $1 / 4 \mathrm{z}$ nich zmielono moździerzem agatowym. Procedura ta pozwoliła wytworzyć drobny jednorodny proszek, który następnie przechowywano w probówce, nad żelem krzemionkowym, w ciemności, do momentu analizy składu chemicznego metodą spektroskopii w podczerwieni z transformatą Fouriera (FTIR).

Spektroskopię FTIR wykonano przy użyciu spektrofotometru FTIR Nicollet 6700 firmy Thermo Electronic Corporation w zakresie częstotliwości $400-4000 \mathrm{~cm}^{-1}$. Aby uzyskać wysoki stosunek sygnału do szumu, zebrano 32 skany dla każdej próbki. Początkowo widma były przystosowane do funkcji parabolicznej. Następnie obliczono RMS (średnią kwadratową) pomiędzy pierwotnym spektrum i tym, które zostało dopasowane przez funkcję. Oprogramowanie Omnic (wersja 8.0), dostarczone przez producenta spektrometru, wykonuje cały proces automatycznie. Kryształ ZnSe w układzie FTIR wynosił $80 \times 10 \mathrm{~mm}$, a jego grubość wynosiła $4 \mathrm{~mm}$. Normalizację wektorową zastosowano do wszystkich widm FTIR zarejestrowanych w badaniu.

Widma standardów zostały przygotowane dla większości związków krystalicznych występujących w kamieniach, takich jak: szczawian wapnia (monohydrat), fosforan magnezowo-amonowy (sześciowodny), kwas moczowy, L-cystyna, węglan wapnia, kwas L-asparaginowy, kwas L-glutaminowy; były one wysokiej jakości (99\%), w czystej formie zakupione od Merck KGaA. Do każdego pomiaru FTIR użyto jednorodnego kamiennego proszku. Wszystkie kamienie nerkowe analizowano przy użyciu metody opisanej przez Slowaya i Wu dla analizy kamicy żółciowej FTIR [7].

\section{WYNIKI}

Typowe widma FTIR 7 różnych standardów przedstawiono na rycinie 1. Następnie widma te porównano z widmami FTIR
TABELA 1. Rodzaje kamieni nerkowych pozyskanych od pacjentów

\begin{tabular}{lcc} 
Rodzaj kamienia & $\begin{array}{c}\text { Liczba kamieni } \\
(\mathbf{n}=\mathbf{4 6})\end{array}$ & Odsetek \\
\hline Kwas moczowy & 5 & $10,9 \%$ \\
\hline Struwit & 13 & $28,3 \%$ \\
\hline Szczawian wapnia & 28 & $58,3 \%$ \\
\hline
\end{tabular}

próbek kamienia nerkowego. Na rycinie 2 przedstawiono widma FTIR niektórych próbek kamienia nerkowego, które były dopasowane na poziomie $\geq 90 \%$ do widm wzorców i zidentyfikowane.

W tabeli 1 przedstawiono rodzaj zidentyfikowanych kamieni nerkowych i ich częstość występowania. Z 46 kamieni nerkowych 58,3\% zidentyfikowano jako szczawian wapnia, 10,3\% jako czysty kwas moczowy, a 28,3\% jako struwit.

W tabeli 2 zestawiono zidentyfikowane piki widma FTIR i przypisano im grupy funkcyjne oraz wiązania chemiczne charakterystyczne dla badanych związków.

Porównanie płci wykazało, że większość (69,6\%) kamieni nerkowych uzyskano od mężczyzn (tab. 3). Porównanie danych wg wieku (tab. 4) ujawniło, że większość kamieni (52,2\%) uzyskano od pacjentów w przedziale 30-44 lat, a najmniej $(8,7 \%)$ od pacjentów w wieku 15-29 lat.

\section{WNIOSKI}

Informacja o składzie chemicznym kamieni nerkowych jest niezbędna do poznania ich etiologii. Terapia kamicy nerkowej opiera się również na analizie kamieni, a dzięki poznaniu składu chemicznego możliwe jest właściwe postępowanie z chorobą i zapobieganie jej nawrotom. Kamienie szczawianowo-wapniowe powstają głównie z powodu choroby metabolicznej - hiperoksalurii (nadmiaru kwasu szczawiowego w moczu) [11]. Szczawiany są produktem końcowym wielu szlaków metabolicznych (w tym związanych z seryną, glicyną, hydroproliną i askorbinianem). Ze źródeł żywieniowych pochodzi 10-20\% szczawianu w moczu, a pokarmy bogate w szczawian to herbata, szpinak i żurawina [11, 12]. Stężenie szczawianu w moczu wpływa na przesycenie szczawianem wapnia, podobnie jak stężenie wapnia w moczu [13]. Stąd każdy stan, który zwiększa wchłanianie szczawianu z pożywienia, może prowadzić do zwiększonego wytwarzania szczawianu i powodować powstawanie kamienia szczawianowego. Hiperkalciuria związana z powstawaniem kamieni może wynikać z wycieku z kanalików nerkowych, zwiększonego wchłaniania wapnia przez przewód pokarmowy i nadczynności przytarczyc [14]. Zredukowane pH moczu może być ważnym czynnikiem ryzyka powstawania kamienia moczowego $[15,16]$. Za zakwaszenie moczu odpowiedzialnych jest kilka procesów. Jednym z mechanizmów jest wytwarzanie $\mathrm{NH}_{3}$ z glutaminy, która zachodzi w kanaliku proksymalnym [17]. Zmniejszone wytwarzanie $\mathrm{NH}_{3}$, powodujące zmniejszoną pojemność buforową dla jonów $\mathrm{H}^{+}$(spowodowane brakiem glutaminy lub defektem enzymatycznym), jest 

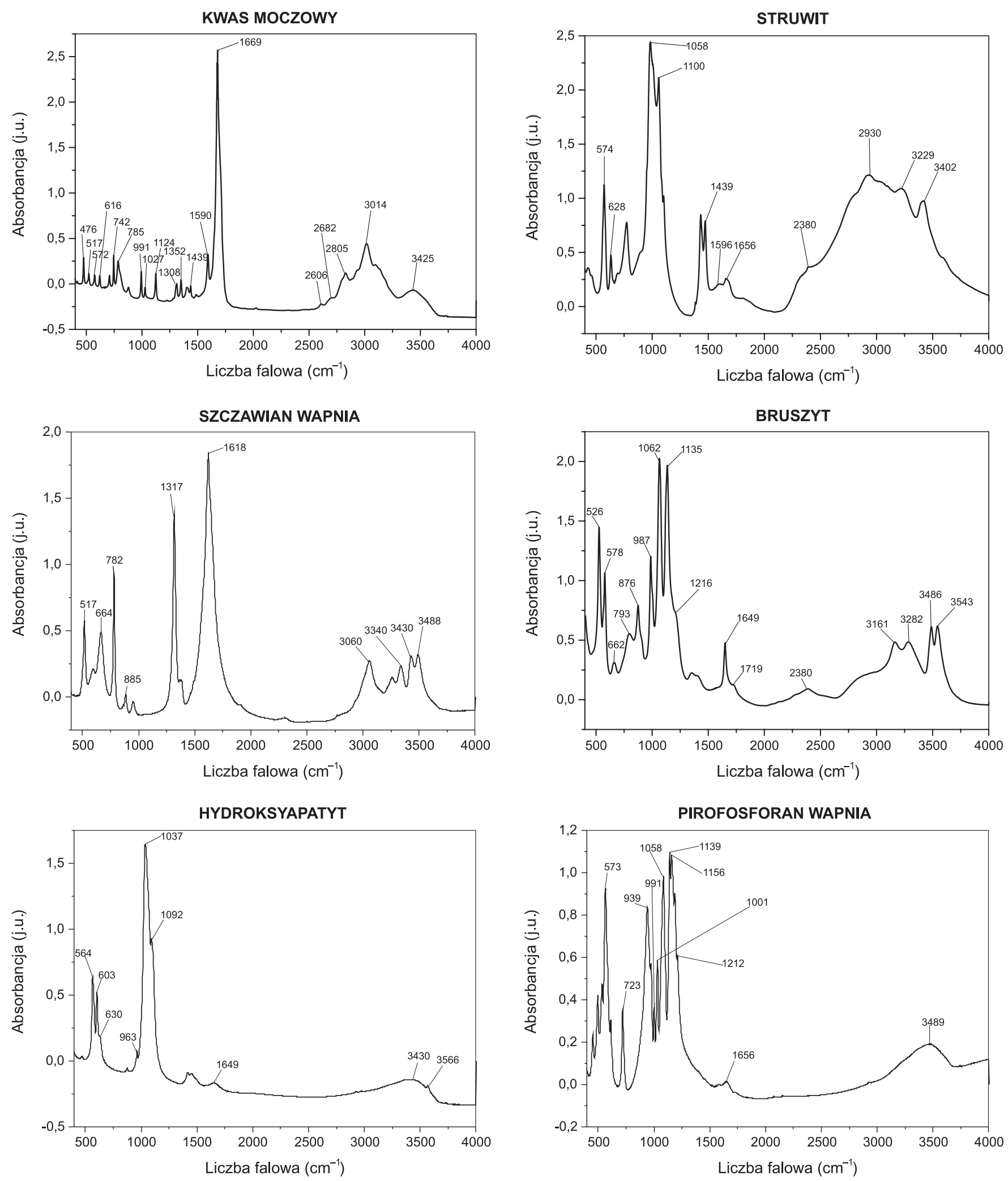

RYCINA 1. Widma FTIR standardów

uważane za potencjalny mechanizm dla trwale niskiego $\mathrm{pH}$ moczu u osób z tendencją do tworzenia się kamieni kwasu moczowego. Kwas moczowy jest końcowym produktem rozkładu puryn u ludzi, a nerka odgrywa główną rolę w jego eliminacji. Podstawy molekularne transportu moczanu nerkowego nie zostały jednak w pełni zdefiniowane. Kamień mocznikowy może być również spowodowany nadmiernym spożyciem mięsa i ryb, chociaż hiperurykozuria wynikająca z dużego spożycia pokarmu wołowego, drobiu i ryb może prowadzić do powstawania kamieni [18]. W badaniu wykryto 28,3\% kamieni struwitu, których powstawanie jest spowodowane infekcją dróg moczowych. Aby zapobiec nawrotom 

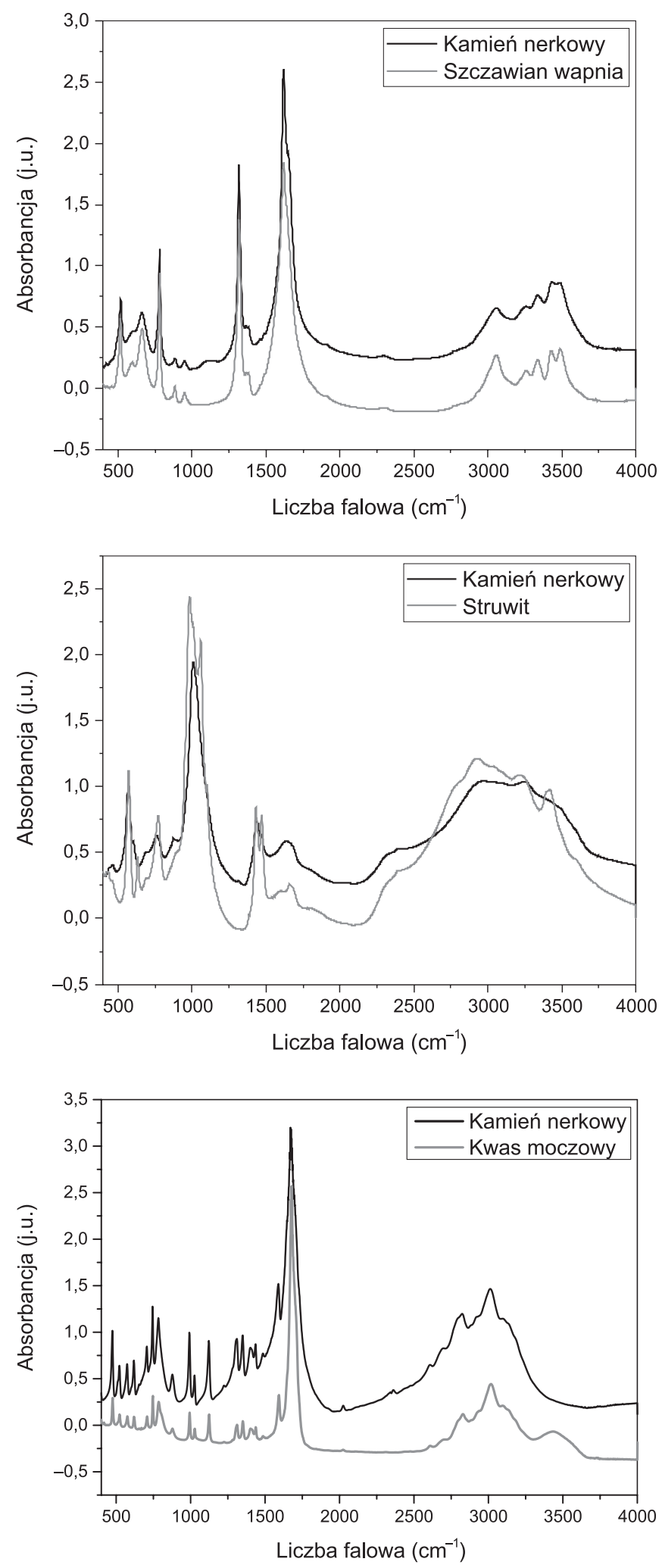

RYCINA 2. Widma FTIR kamieni nerkowych i dopasowane widma standardów

zakażeń, zalecane jest utrzymanie wartości pH moczu poniżej 6,0. Wpływ na pH moczu ma dieta bogata w białko zwierzęce, dieta wegetariańska, napoje bezalkoholowe, napoje bogate w cytrusy i soki cytrusowe [19]. Tego rodzaju kamienie powstają również w wyniku infekcji drobnoustrojami rozszczepiającymi mocznik [12].
Mężczyźni byli w większym stopniu obciążeni przez kamienie nerkowe w porównaniu z kobietami, co może wynikać z niskiej zawartości cytrynianów u mężczyzn w porównaniu z kobietami [20]. Cytrynian jest inhibitorem tworzenia się kamienia, który pochodzi zarówno ze źródeł endogennych (cykl TCA), jak i egzogennych (owoce cytrusowe, takie jak pomarańcze i owoce winogron) [21]. Jednak większość cytrynianu w moczu jest wynikiem wydalania z kanalików nerkowych; gdy wydalanie cytrynianu z cewnika nerkowego zmniejsza się, wówczas dochodzi do hipokitraturii, co prowadzi do powstania kamienia nerkowego [12]. Głównymi czynnikami etiologicznymi związanymi z tym rodzajem kamieni nerkowych są inhibitory krystalizacji moczu (niedobór cytrynianu, fitynianu), wartości pH w moczu poniżej 5,5 i obecność jam w nerkach o niskiej skuteczności urodynamicznej [21].

Z powodu podwójnego działania cytrynianu, będącego zarówno inhibitorem krystalizacji, jak i zwiększającego pH moczu, pokarmy bogate w cytrynian lub leki cytrynianowe są podstawą najskuteczniejszego leczenia dietetycznego lub farmakologicznego tych kamieni. W takich przypadkach należy kontrolować pH moczu, aby uniknąć wysokich wartości, które mogłyby wywołać tworzenie hydroksyapatytu.

\section{PIŚMIENNICTWO}

1. Baggio B. Genetic and dietary factors in idiopathic calcium nephrolithiasis: what do we have, what dowe need? J Nephrol 1999;12:371-4.

2. Uribarri J, Oh MS, Carroll HJ. The first kidney stone. Ann Intern Med 1989;111:1006-9.

3. Curhan GC, Willett WC, Rimm EB, Stampfer MJ. Family history and risk of kidney stones. J Am Soc Nephrol 1997;8:1568-73.

4. Dussol B, Geider S, Lilova A, Léonetti F, Dupuy P, Daudon M, et al. Analysis of the soluble organic matrix of five morphologically different kidney stones. Evidence for a specific role of albumin in the constitution of the stone protein matrix. Urol Res 1995;23:45-51.

5. Abdel-Halim RE, Abdel-Halim MR. A review of urinary stone analysis techniques. Saudi Med J 2006;27(10):1462-7.

6. Hiatt RA, Dales LG, Friedman GD, Hunkeler EM. Frequency of urolithiasis in a prepaid medical care program. Am J Epidemiol 1982;115: 255-65.

7. Soloway RD, Wu J. Analysis of gallstones. In: Muraca M, editor. Methods in biliary research. Boca Raton (FL): CRC Press, Inc; 1995. p. $167-90$.

8. Sekkoum K, Cheriti A, Taleb S, Belboukhari N. FTIR spectroscopic study of human urinary stones from El Bayadh district (Algeria). Arab J Chem 2011:1-5.

9. Valamathi D, Leela A, Gunasekaran S. Formation and microanalysis of struvite urinary calculi. Indian J Pure Appl Phys 2010:36-8.

10. Chauhan CK, Joshi MJ. In vitro crystallization, characterization and growth-inhibition study of urinary type struvite crystals. J Cryst Growth 2013:330-7.

11. Michell AR. Urolithiasis - historical, comparative and pathophysiological aspects: a review. J R Soc Med 1989;82(11):669-72.

12. Morton AR, Iliescu EA, Wilson JWL. Investigation and treatment of recurrent kidney stone. Can Med Assoc J 2002;166(2):213-6.

13. Pak CY, Adams-Huet B, Poindexter JR, Pearle MS, Peterson RD, Moe OW. Rapid communication: relative effect of urinary calcium and oxalate on saturation of calcium oxalate. Kidney Int 2004;66:2032-7.

14. Coe FL. Prevention of kidney stone. Am J Med 1981;71:514-6.

15. Gianfrancesco F, Esposito T, Ombra MN, Forabosco P, Maninchedda G, Fattorini $\mathrm{M}$, et al. Identification of a novel gene and a common variant 
TABELA 2. Zidentyfikowane piki na widmie FTIR i przypisane im grupy funkcyjne oraz wiązania chemiczne

\begin{tabular}{|c|c|c|c|}
\hline Lp. & Liczba falc & $\left.\mathrm{cm}^{-1}\right)$ & Przypisane wiązanie \\
\hline & Kwas moczowy & Kamień nerkowy & Zidentyfikowana grupa funkcyjna [8] \\
\hline 1. & 616 & 618 & wiązanie C-N w pierścieniu aromatycznym \\
\hline 2. & 742 & 743 & wiązanie C-N w pierścieniu aromatycznym, drgania rozciągające \\
\hline 3. & 785 & 785 & wiązanie $\mathrm{C}-\mathrm{H}$, drgania zginające i wiązanie $\mathrm{O}-\mathrm{H}$, drgania zginające w płaszczyźnie \\
\hline 4. & 991 & 990 & grupa $\mathrm{HCO}_{3}^{-}$ \\
\hline 5. & 1027 & 1028 & wiązanie C-N w = C-N \\
\hline 6. & 1124 & 1119 & wiązanie C-N, drgania wibracyjne \\
\hline 7. & 1308 & 1307 & grupa $\mathrm{NO}_{3}^{-}$ \\
\hline 8. & 1352 & 1350 & grupa $\mathrm{NO}_{3}^{-}$ \\
\hline 9. & 1439 & 1438 & wiązanie $\mathrm{C}=\mathrm{C}$, drgania rozciągające \\
\hline 10. & 1590 & 1586 & wiązanie $\mathrm{C}=\mathrm{O}$ w amidzie \\
\hline 11. & 1669 & 1667 & wiązanie $\mathrm{C}=\mathrm{O}$ w grupie mocznikowej \\
\hline 12. & 2606 & 2605 & wiązanie $\mathrm{N}-\mathrm{H}$, drgania rozciągające \\
\hline 13. & 2682 & 2679 & wiązanie $\mathrm{N}-\mathrm{H}$, drgania rozciągające \\
\hline 14. & 2805 & 2805 & wiązanie N-H, drgania rozciągające \\
\hline 15. & 3014 & 3016 & wiązanie $\mathrm{N}-\mathrm{H}$, drgania rozciągające \\
\hline 16. & 3425 & - & - \\
\hline & Szczawian wapnia & Kamień nerkowy & Zidentyfikowana grupa funkcyjna [9] \\
\hline 1. & 517 & 519 & grupa $\mathrm{COO}^{-}$, drgania zginająco-rozciągające \\
\hline 2. & 663 & 660 & wiązanie C-C, drgania wibracyjne \\
\hline 3. & 782 & 781 & wiązanie C-C, drgania wibracyjne \\
\hline 4. & 885 & 885 & wiązanie C-C, drgania wibracyjne \\
\hline 5. & 1317 & 1315 & grupa $\mathrm{COO}^{-}$, drgania zginająco-rozciągające \\
\hline 6. & 1618 & 1619 & zaadsorbowana woda, słabe wiązanie $\mathrm{H}-\mathrm{OH}$ \\
\hline 7. & $3060-3488$ & $3051-3489$ & zaadsorbowana woda, stabe wiązanie $\mathrm{H}-\mathrm{OH}$ \\
\hline & Struwit & Kamień nerkowy & Zidentyfikowana grupa funkcyjna [10] \\
\hline 1. & 574 & 567 & grupa $\mathrm{PO}_{4}{ }^{3-}$ \\
\hline 2. & 628 & 601,677 & Me-O \\
\hline 3. & 1058 & 1032 & grupa $\mathrm{PO}_{4}^{3-}$ \\
\hline 4. & 1100 & 1085 & grupa $\mathrm{PO}_{4}{ }^{3-}$, drgania wibracyjne \\
\hline 5. & 1439 & 1435 & $\begin{array}{l}\text { wiązania } \mathrm{P}-\mathrm{H} \text {, } \\
\text { grupa } \mathrm{PO}_{4}^{3-} \text {, drgania rotacyjne }\end{array}$ \\
\hline 6. & 1596 & - & drgania zginające N-H \\
\hline 7. & 1656 & 1640 & drgania zginające N-H \\
\hline 8. & $2380,2930,3229,3402$ & $2366,2956,3251$ & wiązania O-H i N-H, drgania rozciągające \\
\hline
\end{tabular}

TABELA 3. Porównanie kamieni pozyskanych od pacjentów względem płci

\begin{tabular}{lcc}
\multicolumn{1}{r}{ Płeć } & Liczba kamieni & Odsetek \\
\hline Mężczyzna & 32 & $69,6 \%$ \\
\hline Kobieta & 14 & $30,4 \%$ \\
\hline
\end{tabular}

TABELA 4. Porównanie kamieni pozyskanych od pacjentów względem wieku

\begin{tabular}{lcc} 
Wiek (lata) & Liczba pacjentów $(\mathbf{n}=\mathbf{4 6})$ & Odsetek \\
\hline $15-29$ & 4 & $8,7 \%$ \\
\hline $30-44$ & 24 & $52,2 \%$ \\
\hline $45-60$ & 11 & $23,9 \%$ \\
\hline$>60$ & 7 & $15,2 \%$ \\
\hline
\end{tabular}


associated with uric acid nephrolithiasis in a sardinian genetic isolate. Am J Hum Genet 2003;72:1479-91.

16. Ombra MN, Forabosco P, Casula S, Angius A, Maestrale G, Petretto E, et al. Identification of a new candidate locus for uric acid nephrolithiasis. Am J Hum Genet 2001;68:1119-29.

17. Hamm LL, Simon EE. Roles and mechanisms of urinary buffer excretion. Am J Physiol 1987;253:595-605.
18. Coe FL, Andrew E, Wooster E. Renal section, University of Chicago, Chicago. lllinois, USA. J Clin Invest 2005;115(10):2598-602.

19. Grases F, Costa-Bauza A, Prieto RM. Renal lithiasis and nutrition. Nutr J 2006;5:23-9.

20. Wrong 0, Davies HEF. The excretion in renal disease. Q J Med 1959;28:259-311.

21. Ryall R, Hibberd C, Marshall VA. Method for studying inhibitory activity in whole urine. Urol Res 1987;13:285-9. 